\title{
EVALUATION OF THE ANTIVIRAL ACTIVITY OF Ballota glandulosissima Hub.-Mor. \& Patzak EXTRACTS AGAINST RESPIRATORY SYNCYTIAL VIRUS (RSV)
}

\author{
Hasan Hüseyin DOĞAN*, Rüstem DUMAN \\ Selçuk University, Science Faculty, Biology Department, Campus, Konya, TURKEY \\ *Corresponding author: ORCID ID: orcid.org/0000-0001-8859-0188, e-mail: hhuseyindogan@yahoo.com
}

Cite this article as:

Doğan H.H., Duman R. 2019. Evaluation of the Antiviral Activity of Ballota glandulosissima Hub.-Mor. \& Patzak Extracts Against Respiratory Syncytial Virus (Rsv). Trakya Univ J Nat Sci, 20(2): 121-127, DOI: 10.23902/trkjnat.543382

Received: 22 March 2019, Accepted: 11 September 2019, Online First: 16 September 2019, Published: 15 October 2019

\begin{abstract}
In order to find new and effective antiviral agents from natural sources, the antiviral properties of methanol and aqueous extracts of Ballota glandulosissima Hub.-Mor. \& Patzak were evaluated by Colorimetric XTT test against Respiratory syncytial virus (RSV). The concentration required to provide $50 \%$ protection against cytopathic effects caused by the virus was defined as $\mathrm{EC}_{50}$, the selectivity index (SI) was determined from the ratio of $\mathrm{CC}_{50}\left(50 \%\right.$ Cytotoxic concentration) to $\mathrm{EC}_{50}$. The results showed that both the methanol $\left(\mathrm{EC}_{50}=12.45 \mu \mathrm{g} / \mathrm{mL} ; \mathrm{SI}=24.84\right)$ and aqueous extracts $\left(\mathrm{EC}_{50}=19.12 \mu \mathrm{g} / \mathrm{mL} ; \mathrm{SI}=\right.$ 24.59) of B. glandulosissima had almost the same strong anti-RSV activity as well as ribavirin, used as a positive control against RSV $\left(\mathrm{EC}_{50}=3.25 \mu \mathrm{g} / \mathrm{mL}, \mathrm{SI}=34.89\right)$. In conclusion, we can say that $B$. glandulosissima extracts are worthy of further studies in order to develop an alternative to the drugs used in clinical practice against RSV. This is the first report on the antiRSV activity of $B$. glandulosissima.
\end{abstract}

Key words: Ballota glandulosissima, methanol and aqueous extracts, antiviral activity, respiratory syncytial virus.

Özet: Doğal kaynaklardan yeni ve etkili antiviral etkenler bulmak amacıyla yapılan bu çalışmada, Ballota glandulosissima Hub.-Mor. \& Patzak'dan elde edilen metanol ve su ekstraktlarının antiviral özellikleri Respiratuvar Sinsityal Virus (RSV)'una karşı kolorimetrik XTT testi ile değerlendirilmiştir. Virüsün neden olduğu sitopatik etkilere karş1 \%50 koruma sağlamas1 için gerekli konsantrasyon $\mathrm{EC}_{50}$ olarak tanımlanmış, $\mathrm{CC}_{50}$ (\%50 Sitotoksik Konsantrasyon)'nin EC $\mathrm{E}_{50}$ 'ye oranından da seçicilik indeksi (SI) belirlenmiştir. Araştırma sonucunda, B. glandulosissima'nın hem metanol (EC $\mathrm{EC}_{50}=12.45$ $\mu \mathrm{g} / \mathrm{mL} ; \mathrm{SI}=24.84)$ hem de su ekstraktının $\left(\mathrm{EC}_{50}=19.12 \mu \mathrm{g} / \mathrm{mL}\right.$; SI = 24.59) RSV'ye karşı; pozitif kontrol olarak kullanılan ribavirin $\left(\mathrm{EC}_{50}=3.25 \mu \mathrm{g} / \mathrm{mL}, \mathrm{SI}=34.89\right)$ 'e göre önemli sayllabilecek oranda anti-RSV aktiviteye sahip olduğu tespit edilmiştir. Sonuç olarak, B. glandulosissima ekstraktlarının, RSV'ye karşı klinikte kullanılan ilaçlara karşı bir alternatif olarak geliştirilebilmesi için; daha ileri çalışmalara layık olduğunu söyleyebiliriz. Bu çalışma, B. glandulosissima'nın antiRSV aktivitesine yönelik ilk rapordur.

\section{Introduction}

Acute respiratory infections caused by viruses are a major reason of morbidity and mortality in children worldwide. Human Respiratory Syncytial Virus (HRSV) is the most important cause of pneumonia and bronchiolitis in infants, young children and adults (Hruska et al. 1982, Treanor \& Falsey 1999) and can be destructive in immunosuppressed populations (Wyde et al. 1998). In addition, recurrent infections are a common phenomenon showing that naturally acquired immunity does not provide long-term protection (Dubovi et al. 1981). Although many vaccine development studies have been conducted on RSV, efforts to develop effective vaccines against RSV have been unsuccessful (Chin et al. 1969, Kim et al. 1969, Wyde et al. 1998). Moreover, even if the use of one of the vaccines developed is accepted, this may not be appropriate in some RSV-sensitive populations, e.g., in very young infants and in immunocompromised individuals (Wyde et al. 1998). Ribavirin (RBV) and immunoglobulins containing high titer RSV-specific neutralizing antibodies are currently recognized as antivirals for the treatment and prevention of RSV infections (Kneyber et al. 2000) although they are expensive and not easy to apply. For instance, RBV has been reported to be myelocytotoxic when administered intravenously, and therefore it is only allowed to be used as small aerosol particles (Smith et al. 1991, Lewinsohn et al. 1996).

Aerosol administration of drugs to patients, especially babies and children, is difficult to control and use at home, and therefore patients should go to hospitals for chemotherapy. The absence of a vaccine available to 
prevent RSV and the presence of RBV as the single antiviral agent used only in severe infections are still a problem in pediatric medicine. Therefore, it is necessary to develop specific anti-RSV drugs that can be administered orally or parentally (Ma et al. 2002).

Ballota L. species are perennial herbaceous plants belonging to the Lamiaceae family. The genus Ballota is represented by 35 species and 14 subspecies in the world of which 12 species and 8 subspecies are present in Turkey. The rate of endemism in high with 8 species in Turkey (Davis 1982, Greuter \& Raus 1998, Patzak 1958, Patzak 1960). The genus is well known in Europe due to its spasmolytic and sedative effects (Garnier et al. 1961), and its members are called in different regions of Turkey with the local names şalba, çalba, balotu, ballık otu, nemnem otu, 1sırgan, gezgez otu, köpek otu, karayer pırasas1, elkurtaran, pat pat otu, leylim kara, somruk and karınca somurcağı. Some species are used by people in the treatment of cough, asthma, headache, nausea, haemorrhoid and wound (Baytop 1984, Eryaşar \& Tuzlac1 1998, Meriçli et al. 1988, Tolon Fenercioğlu \& Tuzlacı 1998, Tuzlacı \& Tolon 2000, Yeşilada et al. 1993, Yeşilada et al. 1995). The main components of Ballota species are flavonoids, labdan diterpenoids and phenyl propanoids. Diterpenoids (hispanolone, ballonigrine, dehydrohispanolone) and 14 flavonoids (kumatakenin (jaranol), pachypodol, 5-hydroxy-7,3',4' trimethoxy flavone, velutin, velutol, salvigenol, korimbosol, retusol, corymbosine, 5-hydroxy 3,7,4'trimethoxyflavone, retusin, 5-hydroxy 7, 4'dimethoxy flavone, flindulatine, ladanein) were isolated from different Ballota species and chemically characterized and analyzed by HPLC (Çitoğlu et al. 1998, Çitoğlu et al. 1999, Saltan Çitoğlu et al. 2003a, Saltan Çitoğlu et al. 2003b). Pachypodol (Ro 09-0179) was first isolated from Plectranthus cylindraceus, Pogostemon cablin, Heterotheca grandiflora, Aglaia andamanica, Euodia glabra and Larrea tridentata (Valesi et al. 1972, Fraser \& Lewis 1973, Sakakibara et al. 1976, Wollenweber et al. 1985, Miyazawa et al. 2000, Orabi et al. 2000) has antiviral effect against RNA virus such as poliovirus and rhinovirus. This antiviral effect was shown by inhibiting RNA polymerase in viral RNA synthesis and inhibiting viral replication (Arita et al. 2015, Ishitsuka et al. 1986, Ninomiya et al. 1985, Pérez \& Carrasco 1992). Some of these flavonoids isolated from B. glandulosissima, a species naturally growing in southern Anatolia, has also been reported to have antimicrobial activity (Saltan Çitoğlu et al. 2003a, Saltan Çitoğlu et al. 2003b).

Although it is well reported that Ballota species have antinociceptive, anti-inflammatory, hepatoprotective, antilisterial, antiproliferative and antioxidant activities (Çitoğlu et al. 1998, Çitoğlu et al. 1999, Saltan Çitoğlu et al. 2003a, Saltan Çitoğlu et al. 2003b, Erdoğan-Orhan et al. 2010, Özbek et al. 2004, Rigano et al. 2016, Saltan Çitoğlu et al. 2004a, Saltan Çitoğlu et al. 2004b, Saltan Çitoğlu et al. 2004c, Sever Yılmaz et al. 2005, Sever
Yilmaz et al. 2006), researches on the antiviral activities of Ballota species with different biological activities are limited only to picornaviruses. Ballota species, which have different components one of which is pachypodol, have not been searched for antiviral activity against HRSV.

This study aimed to find new and reliable antiviral agents against RSV. For this purpose, crude extracts obtained from B. glandulosissima were used to evaluate the antiviral activity against RSV.

\section{Materials and Methods}

\section{Plant materials}

Ballota glandulosissima specimens were collected from Antalya in 2016 during flowering period (in July). The samples were identified by Prof. Dr. Osman TUGAY from Pharmacy Faculty of Selçuk University. Aerial parts of the specimens were dried in the shade, ground into a fine powder by a mill and stored in sterile black glass jars at room temperature. A voucher sample is kept at KNYA Herbarium, Selcuk University, Science Faculty, Biology Department, Konya, Turkey.

\section{Preparation of the extracts}

$20 \mathrm{~g}$ powder samples were placed separately in $400 \mathrm{ml}$ of methanol and $400 \mathrm{ml}$ of sterile distilled water and extracted for 1 hour with an ultrasonicator at $37^{\circ} \mathrm{C}$. The extracts were filtered through Whatman No: 1 filter paper, and the solvents used were completely evaporated at $40^{\circ} \mathrm{C}$ under reduced pressure in a rotary evaporator (Heidolph Laborota 4000, Germany). After evaporation, the extracts were lyophilized at $-110^{\circ} \mathrm{C}$ under reduced pressure in a lyophilizer (Labconco, USA). Each $1000 \mathrm{mg}$ of the lyophilized methanol and aqueous extracts were dissolved in $10 \mathrm{~mL}$ of EMEM (serum-free) and stock solutions were prepared at a concentration of $100 \mathrm{mg} / \mathrm{mL}$. The stock solutions were sterilized with $0.22 \mu \mathrm{m}$ Millipore filter, put in $2 \mathrm{~mL}$ tubes at a rate of $1 \mathrm{~mL}$ concentrations and stored at $+4{ }^{\circ} \mathrm{C}$ until use. Dilutions of the extracts for cytotoxicity and antiviral activity tests were prepared from these stocks. Ribavirin (RBV, R9644-10 mg, Sigma, USA), a drug approved for the treatment of RSV infections in humans, was purchased and used as positive control. 10 $\mathrm{mg}$ RBV was dissolved in $5 \mathrm{~mL}$ of EMEM (serum-free). This $2 \mathrm{mg} / \mathrm{mL}$ stock concentration were filtered with a $0.22 \mu \mathrm{m}$ Millipore filter and stored at $-80^{\circ} \mathrm{C}$ or $+4^{\circ} \mathrm{C}$ (When stored at $+4^{\circ} \mathrm{C}$, it was used within 1 week).

\section{Cells and the virus}

Human larynx epidermoid carcinoma cells [HEp-2; ATCC (the American Type Culture Collection) CCL 23] were used to culture HRSV (RSV Long strain: ATCC VR-26). Reagents and medium for cell culture were purchased from different companies. Cells were propagated at $37^{\circ} \mathrm{C}$ under $5 \% \quad \mathrm{CO}_{2}$ in EMEM supplemented with $10 \%$ fetal bovine serum (FBS, ATCC30-2020), $10000 \mathrm{U} / \mathrm{mL}$ penicillin, $10 \mathrm{mg} / \mathrm{mL}$ streptomycin and $25 \mu \mathrm{g} / \mathrm{mL}$ amphotericin B. The virus was propagated on $90 \%$ confluent cell monolayer in 
EMEM with 2\% FBS and antibiotics as described above. Viral titer was determined by $50 \%$ tissue culture infectious dose $\left(\right.$ TCID $_{50}$ ) method and expressed as TCID $_{50}$ per $0.1 \mathrm{~mL}$ (Kaerber 1964). The virus was stored at $-80^{\circ} \mathrm{C}$ until use.

\section{Cytotoxicity assay}

The method described by Eskiocak et al. (2008) was used to determine the cytotoxic effects of RBV and methanol and aqueous extracts of B. glandulosissima on HEp-2 cells.

The cytotoxicity test was carried out as follows;

First column of a 96-well microplate was used as the medium control (MC) and $150 \mu \mathrm{L}$ EMEM (serum-free) was added in each of the 8 wells contained in this column. Except for the $3^{\text {rd }}$ column, $100 \mu \mathrm{L}$ EMEM (serum-free) was put in the remaining 10 columns (viz, 2, 4, 5, 6, 7, 8, $9,10,11$ and 12 column). An experiment solution of 2 $\mathrm{mg} / \mathrm{mL}(2000 \mu \mathrm{g} / \mathrm{mL})$ was prepared using EMEM (serum-free) from stock solution of the extracts (100 $\mathrm{mg} / \mathrm{mL})$.

$200 \mu \mathrm{L}$ from experiment solution of the extracts were added in each of the 8 wells in the $3^{\text {rd }}$ column and serial two fold dilutions according to $\log 2$ base (2000, 1000, $500,250,125,62.5,31.25,15.63,7.81,3.91 \mu \mathrm{g} / \mathrm{mL})$ were prepared. The second column of the microplate was used as cell control (CC).

The same procedures were performed for RBV using another microplate. First column of the microplate was used as MC and $150 \mu \mathrm{L}$ EMEM (serum-free) were put in each of the 8 wells. Except for the $3^{\text {rd }}$ column, $100 \mu \mathrm{L}$ EMEM (serum-free) was put in the remaining 10 columns (viz, 2, 4, 5, 6, 7, 8, 9, 10, 11 and 12 column). An experiment solution of $750 \mu \mathrm{g} / \mathrm{mL}$ was prepared by using serum-free EMEM from stock solution of RBV (2000 $\mu \mathrm{g} / \mathrm{mL}) .200 \mu \mathrm{L}$ RBV from $750 \mu \mathrm{g} / \mathrm{mL}$ experiment solution was placed in each of the 8 wells. Serial two fold dilutions were made from the $3^{\text {rd }}$ to the $12^{\text {th }}$ columns $(750$, $375,187.5,93.75,46.88,23.44,11.72,5.86,2.93$ and 1.46 $\mu \mathrm{g} / \mathrm{mL})$.

$50 \mu \mathrm{L}$ HEp- 2 cell suspensions containing $1 \times 10^{5}$ cells per $\mathrm{mL}$ were added to each well in columns 2 to 12 making the final concentrations of the extracts in the wells as $1333.33,666.67,333.33,166.67,83.33,41.67,20.83$, $10.42, \quad 5.21$ and $2.60 \mu \mathrm{g} / \mathrm{mL}$, while the final concentrations of RBV in the wells were 500.00, 250.00, $125.00,62.50,31.25,15.63,7.81,3.91,1.95$ and 0.98 $\mu \mathrm{g} / \mathrm{mL}$. The plates were incubated in $5 \% \mathrm{CO}_{2}$ humidified incubator at $37^{\circ} \mathrm{C}$ for 3 days. Then $50 \mu \mathrm{L}$ suspensions mixed with $5 \mathrm{~mL}$ XTT reagent and $0.1 \mathrm{~mL}$ PMS activator were placed in each well. The plates were incubated for a further 3 hours to form the XTT formazan product. Optical densities (OD) were recorded in an ELISA reader (Multiskan EX, Labsystems) at a test wavelength of 490 $\mathrm{nm}$ and a reference wavelength of $630 \mathrm{~nm}$ to record OD averages from 8 wells. The test was performed in triplicate and the results were shown as the ratio of the average cytotoxicity to the cell control.

The following formula was used to calculate the percentage of cytotoxicity of the extracts on HEp-2 cells and RBV.

$$
\text { Cytotoxicity }(\%)=\frac{(\mathrm{A}-\mathrm{B})}{\mathrm{A}} \times 100
$$

A: The optical density of cell control

B: The optical density for the cells treated with extracts or RBV.

The cytotoxicity percentages calculated were plotted according to the corresponding concentrations of the tested samples (extracts and RBV). 50\% cytotoxic concentration $\left(\mathrm{CC}_{50}\right)$, defined as the concentration reducing the OD values of the cells treated with extracts or RBV by up to $50 \%$ compared with $\mathrm{CC}$, was determined with non-linear regression analysis run in the GraphPad Prism Version 5.03 statistical program. The maximum non-toxic concentrations (MNTCs) of the extracts and RBV were also determined by comparing OD with CC. These MNTCs were used to determine the antiviral activity of the extracts and RBV.

\section{Antiviral activity assay}

After MNTCs were determined against HEp-2 cells, 10 times more concentrated dilutions of the extracts and RBV were prepared. The dilutions were diluted according to $\log _{2}$ base and their antiviral activities against RSV (diluted at 100 DKID $_{50}$ dose) were tested by XTT method (Chiang et al. 2002). The method was applied as described below;

Suspensions were prepared such that the HEp-2 cells were at a concentration of $1.43 \times 10^{5}$ cells $/ \mathrm{mL}$ using $2 \%$ FBS-containing EMEM (cell maintenance medium). From these cell suspensions, the wells of 96-well culture plates (except for 8 wells in the $1^{\text {st }}$ column of the plate used as MC) were seeded at a volume of $70 \mu \mathrm{L}$ per well ( $\sim 10^{4}$ cells / well). $100 \mu \mathrm{L}$ aliquots of cell maintenance medium were placed in 8 wells used as $\mathrm{MC}$ and incubated in $5 \% \mathrm{CO}_{2}$ at $37^{\circ} \mathrm{C}$ for 4 hours. Then, $20 \mu \mathrm{L}$ of RSV suspension diluted in $100 \mathrm{TCID}_{50} / 0.1 \mathrm{~mL}$ using the maintenance medium were put in the wells (except for 8 wells in the $1^{\text {st }}$ column used for MC and the $2^{\text {nd }}$ column used for CC). 8 wells in the $3^{\text {rd }}$ column of the microplates were used as Virus Control (VC). $20 \mu \mathrm{L}$ aliquots of the maintenance medium were placed in 8 wells in the $2^{\text {nd }}$ column used as CC and the plate was incubated for 2 hours. $10 \times$ MNTC dilutions containing 2\% FBS were prepared from stock solutions $(100 \mathrm{mg} / \mathrm{mL})$ of the extracts. Subsequently, serial two fold dilutions $[(10 \times \mathrm{MNTC}) / 2, \quad(10 \times \mathrm{MNTC}) / 4, \quad(10 \times \mathrm{MNTC}) / 8$, $(10 \times \mathrm{MNTC}) / 16, \quad(10 \times \mathrm{MNTC}) / 32, \quad(10 \times \mathrm{MNTC}) / 64$, $(10 \times \mathrm{MNTC}) / 128, \quad(10 \times \mathrm{MNTC}) / 256]$ using the maintenance medium were prepared from the extract solutions of $10 \times$ MNTC concentrations. After incubation for 2 hours, $10 \mu \mathrm{L}$ of the dilutions prepared $10 \times \mathrm{MNTC}$ 
concentration were put in 8 wells of the $4^{\text {th }}$ column. In the remaining 8 columns of the microplates (viz, wells on columns $5,6,7,8,9,10,11$ and 12$), 10 \mu \mathrm{L}$ of the extract dilutions $[(10 \times \mathrm{MNTC}) / 2,(10 \times \mathrm{MNTC}) / 4,(10 \times \mathrm{MNTC}) / 8$, $(10 \times \mathrm{MNTC}) / 16, \quad(10 \times \mathrm{MNTC}) / 32, \quad(10 \times \mathrm{MNTC}) / 64$, $(10 \times \mathrm{MNTC}) / 128,(10 \times \mathrm{MNTC}) / 256]$ were added to the each well.10 $\mu \mathrm{L}$ cell maintenance medium was placed in the wells of the microplates used as CC and VC wells. The same procedures were also performed for RBV using another microplate. A dilution of $10 \times \mathrm{MNTC}$ containing $2 \%$ FBS was prepared from the stock solution (1000 $\mu \mathrm{g} / \mathrm{mL})$ of RBV. Subsequently, two fold dilutions $[(10 \times \mathrm{MNTC}) / 2, \quad(10 \times \mathrm{MNTC}) / 4, \quad(10 \times \mathrm{MNTC}) / 8$, $(10 \times \mathrm{MNTC}) / 16, \quad(10 \times \mathrm{MNTC}) / 32, \quad(10 \times \mathrm{MNTC}) / 64$, $(10 \times \mathrm{MNTC}) / 128, \quad(10 \times \mathrm{MNTC}) / 256]$ using the maintenance medium were prepared from the RBV solution in $10 \times$ MNTC. Next, the steps in determining the antiviral activity of the extracts were followed. The plates were incubated in $5 \% \mathrm{CO}_{2}$ at $37^{\circ} \mathrm{C}$ for 3 days. Then, $5 \mathrm{~mL}$ of the XTT reagent was mixed with $0.1 \mathrm{~mL}$ of the PMS activator and $50 \mu \mathrm{L}$ was added to each well. The plates were gently shaken to homogeneously distribute the dye into the wells. The plates were incubated for a 3 hours to form the XTT formazan product. OD values were read at $490 \mathrm{~nm}$ test and $630 \mathrm{~nm}$ reference wavelengths in an ELISA reader, and OD averages from 8 wells were recorded. The protection percentages of extracts or RBV concentrations against viruses were calculated from the following formula where $\mathrm{A}, \mathrm{B}$ and $\mathrm{C}$ indicate the absorbance of the extracts or RBV, the virus and the cell controls, respectively (Andrighetti-Fröhner et al. 2003):

Protection percentage $=[(\mathrm{A}-\mathrm{B}) /(\mathrm{C}-\mathrm{B}) \times 100]$

$\mathrm{EC}_{50}$ value, defined as the concentration of the extracts or RBV that provides protection in $50 \%$ of the infected cells, was determined using nonlinear regression analysis in GraphPad Prism Version 5.03 taking into account the $\%$ protection rates determined with extract or RBV concentrations. The selectivity index (SI) of the extracts and $\mathrm{RBV}$ was calculated from the $\mathrm{CC}_{50} / \mathrm{EC}_{50}$ ratio. The experiments were done in triplicate.

\section{Results}

\section{Virus titration}

Titres of RSV in HEp-2 cells were determined as $\operatorname{TCID}_{50}=10^{-4} / 0.1 \mathrm{~mL}$ at the end of the $3^{\text {rd }}$ day.

\section{Cytotoxicity assay}

In order to determine the MNTC and $\mathrm{CC}_{50}$ values of B. glandulosissima methanol and aqueous extracts against HEp-2 cells, the obtained cytotoxicity rates are shown in Table 1 and Fig. 1, respectively. The $\mathrm{CC}_{50}$ value of $B$. glandulosissima methanol extract was determined as $309.30 \mu \mathrm{g} / \mathrm{mL}$ and the MNTC as $10.42 \mu \mathrm{g} / \mathrm{mL}$. The $\mathrm{CC}_{50}$ and MNTC of B. glandulosissima aqueous extract were determined as $470.1047 \mu \mathrm{g} / \mathrm{mL}$ and $2.60 \mu \mathrm{g} / \mathrm{mL}$ (Table 1 and Fig. 1). The MNTC and $\mathrm{CC}_{50}$ values $(113.40 \mu \mathrm{g} / \mathrm{mL}$ and $0.98 \mu \mathrm{g} / \mathrm{mL}$, respectively) of RBV are shown in Table 1 and Fig. 1.
Table 1. The results of cytotoxicity and antiviral activity assays for RBV and methanol and aqueous extracts of $B$. glandulosissima.

\begin{tabular}{|c|c|c|c|c|c|}
\hline & \multirow{2}{*}{ 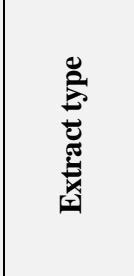 } & \multicolumn{2}{|c|}{ 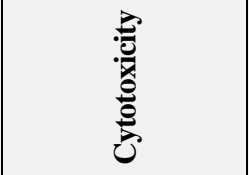 } & \multicolumn{2}{|l|}{ 㺼 } \\
\hline & & $\begin{array}{l}\text { MNTC } \\
(\mu \mathrm{g} / \mathrm{mL})\end{array}$ & $\begin{array}{c}\mathrm{CC}_{50} \\
(\mu \mathrm{g} / \mathrm{mL})\end{array}$ & $\begin{array}{c}\mathrm{EC}_{50} \\
(\mu \mathrm{g} / \mathrm{mL})\end{array}$ & SI \\
\hline $\begin{array}{ll}B . \\
\end{array}$ & Methanol & 10.42 & 309.30 & 12.45 & 24.84 \\
\hline glandulosissima & Aqueous & 2.60 & 470.10 & 19.12 & 24.59 \\
\hline $\begin{array}{c}\text { Ribavirin } \\
\text { (RBV) }\end{array}$ & -- & 0.98 & 113.40 & 3.25 & 34.89 \\
\hline
\end{tabular}

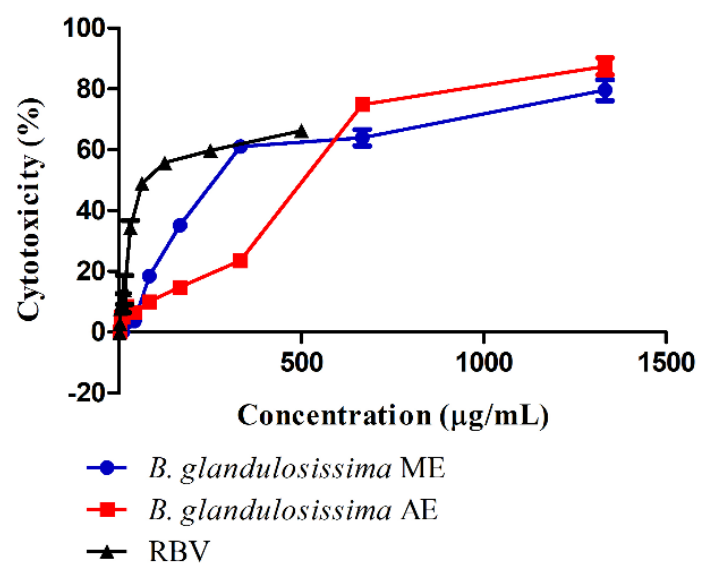

Fig. 1. Cytotoxic activities of methanol and aqueous extracts of B. glandulosissima and RBV.

\section{$\underline{\text { Antiviral activity assay }}$}

Percentage protection rates of methanol and aqueous extracts starting from MNTC dilutions against RSV are shown in Table 1. The $\mathrm{EC}_{50}$ values of methanol and aqueous extracts were determined as $12.45 \mu \mathrm{g} / \mathrm{mL}$ and $19.12 \mu \mathrm{g} / \mathrm{mL}$, respectively (Fig. 2). SI $\left(\mathrm{CC}_{50} / \mathrm{EC}_{50}\right)$ values of methanol and aqueous extracts are 24.84 and 24.59, respectively (Table 1).

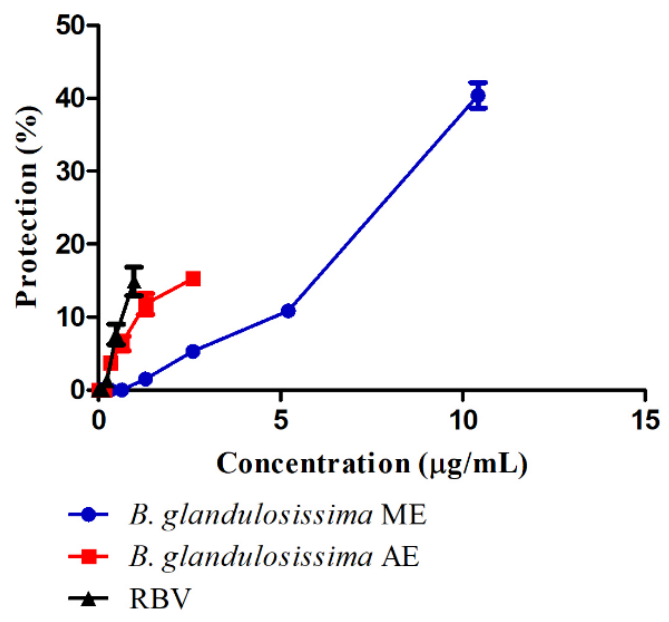

Fig. 2. Antiviral activities of methanol and aqueous extracts of B. glandulosissima and RBV. 
The protection rates of RBV against RSV are given in Table 1. The $\mathrm{EC}_{50}$ value of RBV was determined as 3.25 $\mu \mathrm{g} / \mathrm{mL}$ (Fig. 2). The selectivity index (SI) of the RBV was determined as 34.89 from the $\mathrm{CC}_{50} / \mathrm{EC}_{50}$ ratio (Table 1).

\section{Discussion}

RSV is the most common cause of acute respiratory infections in infants and children. Although the mortality rate is generally low, it can also cause heart or respiratory failure up to $37-73 \%$ and bone marrow transplantation up to $36-45 \%$ in infants (Kimura et al. 2000, MacDonald et al. 1982, Englund et al. 1988, Harrington et al. 1992). Original anti-RSV compounds with better efficacy and safety than ribavirin have been the target of researches. Natural products may constitute different sources of antiviral agents. For example, pachypodol was isolated from many plant species, in addition to $B$. glandulosissima, and it has been reported to have antiviral activity against RNA viruses such as poliovirus and rhinovirus (Arita et al. 2015, Ishitsuka et al. 1986, Ninomiya et al. 1985, Pérez \& Carrasco 1992).

Cytotoxic and antiviral activities of methanol and aqueous extracts prepared from the aerial parts of $B$. glandulosissima and RBV were evaluated by colorimetric XTT test (see Table 1. The results showed that the extracts with $\mathrm{CC}_{50}$ values in the range of $309.30-470.10 \mu \mathrm{g} / \mathrm{mL}$ were found to be non-toxic to HEp-2 cells according to the criteria of Rukunga \& Simons (2006). According to the classification of Rukunga \& Simons (2006), extracts with a $\mathrm{CC}_{50}$ value less than $2 \mu \mathrm{g} / \mathrm{mL}$ are cytotoxic, extracts with a $\mathrm{CC}_{50}$ value in the range of $2-89 \mu \mathrm{g} / \mathrm{mL}$ are partially (moderately) cytotoxic and extracts with a $\mathrm{CC}_{50}$ value greater than $90 \mu \mathrm{g} / \mathrm{mL}$ are non-toxic.

The antiviral activity experiments revealed that methanol and aqueous extracts of $B$. glandulosissima had a significant antiviral activity comparable to RBV. The $\mathrm{EC}_{50}$ values of the extracts were determined as 12.45 $\mu \mathrm{g} / \mathrm{mL}$ and $19.12 \mu \mathrm{g} / \mathrm{mL}$, respectively, while SI values were determined as 24.84 and 24.59 , respectively. Vanden Berghe \& (1993) suggested that the antiviral

\section{References}

1. Andrighetti-Fröhmer, C.R., Antonio, R.V., CreczynskiPasa, T.B., Barardi, C.R.M. \& Simões, C.M.O. 2003. Cytotoxicity and potential antiviral evaluation of violacein produced by Chromobacterium violaceum. Memórias do Instituto Oswaldo Cruz, 98: 843-848.

2. Arita, M., Philipov, S. \& Galabov, A.S. 2015. Phosphatidylinositol 4-kinase III beta is the target of oxoglaucine and pachypodol (Ro 09-0179) for their antipoliovirus activities, and is located at upstream of the target step of brefeldin A. Microbiology and Immunulogy, 59(6): 338-347.

3. Baytop, T. 1984. Türkiye'de Bitkilerle Tedavi. İstanbul Üniversitesi Yayınları, İstanbul, 371 pp.

4. Chattopadhyay, D., Chawla-Sarkar, M., Chatterjee, T., Dey, R.S., Bag, P., Chakraborti, S. \& Khan, M.T.H. 2009. Recent activity of crude plant extracts should be detectable in at least two consecutive maximum non-toxic dilutions to discriminate between the virus-induced $\mathrm{CPE}$ and the CPE resulting from the toxic effect of the extracts. In addition, Cos et al. (2006) defined quality standards for basic evaluation of activity screening of natural products. As a standard for the antiviral efficacy of natural products, such as plant extracts, investigators have proposed a mandatory endpoint of $\mathrm{EC}_{50}$ values of less than 100 $\mu \mathrm{g} / \mathrm{mL}$. Apart from $\mathrm{EC}_{50}$ values, SI values of 10 or greater are generally reported to be considered as indicators of positive antiviral activity (Chattopadhyay et al. 2009).

In this study, our results showed a parallelism with the studies of Vanden Berghe et al. (1993), Cos et al. (2006) and Chattopadhyay et al. (2009). Extracts with more than two consecutive maximum non-toxic dilution in the concentration of antiviral effect has been determined, and $\mathrm{EC}_{50}$ values less than $100 \mu \mathrm{g} / \mathrm{mL}$ and SI values greater than 10 were obtained. Therefore, it was concluded that the extracts of B. glandulosissima had a reliable antiviral activity. Various components may be responsible for this antiviral activity. For instance, the rich flavonoid components identified in this plant can especially be effective on the virus (Saltan Çitoğlu \& Sever 2002). Saltan Çitoğlu \& Sever (2002) isolated seven flavonoids (kumatakenin (jaranol), pachypodol, 5-hydroxy-7,3',4' trimethoxy flavone, velutin, salvigenin, corymbosin, retusin) from $B$. glandulosissima extracts among which pachypodol has an antiviral effect. This effect is shown by inhibiting RNA polymerase in viral RNA synthesis and inhibiting viral replication (Arita et al. 2015, Ishitsuka et al. 1986, Ninomiya et al. 1985, Pérez \& Carrasco 1992).

This is the first study to determine the anti-RSV activities of $B$. glandulosissima. Therefore, no comparison could have been done with other studies.

\section{Acknowledgement}

The authors would like to thank Selçuk University, Scientific Research Projects Coordinating Office (SÜBAP-16401077).

advancements for the evaluation of antiviral activities of natural products. New Biotechnology, 25: 347-368.

5. Chiang, L.C., Chiang, W., Chang, M.Y., Ng, L.T. \& Lin, C.C. 2002. Antiviral activity of Plantago major extracts and related compounds in vitro. Antiviral Research, 55: 53-62.

6. Chin, J., Magoffin, R.L., Shearer, L.A., Schieble, J.H. \& Lennette, EH. 1969. Field evaluation of a respiratory syncytial virus vaccine and a trivalent parainfluenza virus vaccine in a paediatric population. American Journal of Epidemiology, 89: 449-463.

7. Çitoğlu, G., Tanker, M. \& Sever, B. 1999. Note flavonoid aglycones from B. saxatilis subsp. saxatilis. Pharmaceutical Biology, 37: 158-160.

8. Çitoğlu, G., Tanker, M., Sever, B., Englert, J., Anton, R. \& Altanlar, N. 1998. Antibacterial activities of diterpenoids 
isolated from B. saxatilis subsp. saxatilis. Planta Medica, 64: 484-485.

9. Cos, P., Vlietinck, A.J., Vanden Berghe, D. \& Maes, L. 2006. Anti-infective potential of natural products: how to develop a stronger in vitro 'proof-of concept'. Journal of Ethnopharmacology, 106: 290-302.

10. Davis, P.H. 1982. Flora of Turkey and the East Aegean Islands. Edinburgh University Press, Edinburg, volume 7, 156-160 pp.

11. Dubovi, E.J., Geratz, J.D., Shaver, S.R. \& Tidwell, R.R. 1981. Inhibition of respiratory syncytial virus-host cell interactions by mono and diamidines. Antimicrobial Agents and Chemotherapy, 19: 649-656.

12. Englund, J.A., Sullivan, C.J., Jordan, M.C., Dehner, L.P., Verecellotti, G.M. \& Balfour, F. 1988. Respiratory syncytial virus infection in immunocompromised adults. Annals of Internal Medicine, 109: 203-208.

13. Erdoğan-Orhan, I., Sever-Y1lmaz, B., Altun, M.L. \& Saltan Çitoğlu, G. 2010. Radical quenching activity, ferric reduction antioxidant power, and ferrous ion-chelating capacity of Ballota species and their total phenol and flavonoid contents. Journal of Medicinal Food, 13(6): 1537-1543.

14. Eryaşar, P. \& Tuzlacı, E. 1998. Gönen (Balıkesir) halk hekimliğinde kullanılan bitkiler, 95-102. Paper presented at XII. Bitkisel İlaç Hammaddeleri Toplantıs1, 20-22 May, Hacettepe, Ankara-Turkey.

15. Eskiocak, U., İşeri, O.D., Kars, M.D., Biçer, A. \& Gündüz, U. 2008. Effect of doxorubicin on telomerase activity and apoptotic gene expression in doxorubicin-resistant and sensitive MCF-7 cells: an experimental study. Chemotherapy, 54: 209-216.

16. Fraser, A.W. \& Lewis, J.R. 1973. Two flavonols from Euodia glabra. Phytochemistry 12: 1787-1789.

17. Garnier, G., Debraux, G. \& Bezanger-Beauquesne, L. 1961. Ressources Medicinales de la Flöre Française. Vigot Freres Editeurs, Paris, 1156-1158 pp.

18. Greuter, W. \& Raus, T. 1998. Med-checklist Notulae, 17. Willdenowia, 28: 163-174.

19. Güner, A., Aslan, S., Ekim, T., Vural, M \& Babaç, M.T. (edlr.) (2012). Türkiye Bitkileri Listesi (Damarlı Bitkiler). Nezahat Gökyiğit Botanik Bahçesi ve Flora Araştırmaları Derneği Yayını.

20. Harrington, R.D., Hooton, T.M., Hackman, R.C., Storch, G.A., Osborne, B., Gleaves, C.A., Benson, A. \& Meyers, JD. 1992. An outbreak of respiratory syncytial virus in bone marrow transplant centre. Journal of Infectious Diseases, 165: 987-993.

21. Hruska, J.F., Morrow, P.E., Suffin, S.C. \& Douglas, R.G. 1982. In vivo inhibition of respiratory syncytial virus by ribavirin. Antimicrobial Agents and Chemotherapy, 21: 125-130.

22. Ishitsuka, H., Ninomiya, Y. \& Suhara, Y. 1986. Molecular basis of drug resistance to new antirhinovirus agents. The Journal of Antimicrobial Chemotherapy, 18 Suppl B: 1118.
23. Kaerber, G. 1964. Diagnostic procedures for virus and rickettsial disease. Public Health Association, 3: 48-50.

24. Kim, H.W., Canchola, J.G., Brandt, C.D., Pyles, G., Chanock, R.M., Jensen, K. \& Parrott, R.H. 1969. Respiratory syncytial virus disease in infants despite prior administration of antigenic inactivated vaccine. American Journal of Epidemiology, 89: 422-434.

25. Kimura, K., Mori, S., Tomita, K., Ohno, K., Takahashi, K., Shigeta, S. \& Terada, M. 2000. Antiviral activity of NMSO3 against respiratory syncytial virus infection in vitro and in vivo. Antiviral Research 47: 41-51.

26. Kneyber, M.C.J., Mou, H.A. \& Groot, R.D. 2000. Treatment and prevention of respiratory syncytial virus infection. European Journal of Paediatrics, 159: 339-411.

27. Lewinsohn, D.M., Bowden, R.A., Mattson, D. \& Crawford, S.W. 1996. Phase I study of intravenous ribavirin treatment of respiratory syncytial virus pneumonia after marrow transplantation. Antimicrobial Agents and Chemotherapy, 40: 2555-2557.

28. Ma, S.C., Du, J., But, P.P.H., Deng, X.L., Zhang, Y.W., Ooi, V.E.C., Xu, H.X., Lee, S.H.S. \& Lee, S.F. 2002. Antiviral Chinese medicinal herbs against respiratory syncytial virus. Journal of Ethnopharmacology, 79: 205211.

29. MacDonald, NE., Hall, CB., Suffin, SC., Alexson, C., Harris, PJ. \& Manning, JA. 1982. Respiratory syncytial virus infection in infants with congenital heart disease. New England of Journal Medicine, 307: 397-400.

30. Meriçli, A.H., Meriçli, F. \& Tuzlacı, E. 1988. Flavonoids of Ballota acetabulosa. Acta Pharmaceutica Turcica, 30: 143-144.

31. Miyazawa, M., Okuno, Y., Nakamura, S. \& Kosaka, H. 2000. Antimutagenic activity of flavonoids from Pogostemon cablin. Journal of Agricultural and Food Chemistry, 48(3): 642-647.

32. Ninomiya, Y., Aoyama, M., Umeda, I., Suhara, Y. \& Ishitsuka, H. 1985. Comparative studies on the modes of action of the Antirhinovirus agents Ro 09-0410, Ro 090179, RMI-15,731, 4',6-dichloroflavan and enviroxime. Antimicrobial Agents and Chemotherapy, 27(4): 595-599.

33. Orabi, K.Y., Mossa, J.S., Muhammed, I., Alloush, M.H., Galal, A.M., El-Feraly, F.S. \& McPhail, E.T. 2000. New eudesmane sesquiterpene from Plectranthus cylindraceus. Journal of Natural Products, 63: 1665-1668.

34. Özbek, H., Saltan Çitoğlu, G., Dülger, H., Uğraş, S. \& Sever, B. 2004. Hepatoprotective and anti-inflammatory activities of Ballota glandulosissima. Journal of Ethnopharmacology, 95: 143-149.

35. Patzak, V.A. 1958. Revision der gattung Ballota section Acanthoprasium und section Beringeria. Annalen des Naturhistorischen Museums in Wien, 62: 57-86.

36. Patzak, V.A. 1960. Zwei nene Ballota-arten aus der Türkei nebst einem nachtrag zur gattung Ballota. Annalen des Naturhistorischen Museums in Wien, 64: 42-56.

37. Pérez, L. \& Carrasco, L. 1992. Lack of direct correlation between p220 cleavage and the Shut-off of host translation after Poliovirus infection. Virology, 189: 178-186. 
38. Rigano, D., Marrelli, M., Formisano, C., Menichini, F., Senatore, F., Bruno, M. \& Conforti, F. 2016. Phytochemical profile of three Ballota species essential oils and evaluation of the effects on human cancer cells. Natural Product Research, 17: 1-9.

39. Rukunga, G. \& Simons, A.J. (2006). The potential of plants as a source of antimalarial agents, A review, 72pp, Africa herbal antimalarial meeting, CDE and ICRAF, World Agroforestry Centre, Nairobi, Kenya.

40. Sakakibara, M., Difeo, D., Nakatani, J.N., Timmermann, B. \& Mabry, T.S. 1976. Flavonoid methyl ethers on the external leaf surface of Larrea tridentata and Larrea divaricata. Phytochemistry, 15: 727-731.

41. Saltan Çitoğlu G. \& Sever, B. 2002. Ballota glandulosissima Hub.-Mor \& Patzak ve Ballota inaequidens Hub.-Mor \& Patzak'dan elde edilen flavonoid aglikonlari, 172-181, 14. Bitkisel İlaç Hammaddeleri Toplantıs1, 29-31 Mayıs, Eskişehir, Türkiye.

42. Saltan Çitoğlu, G., Çoban, T., Sever, B. \& İşcan, M. 2004a. Antioxidant properties of Ballota species growing in Turkey. Journal of Ethnopharmacology, 92: 275-280.

43. Saltan Çitoğlu, G., Özbek, H. \& Sever, B. 2004b. Antinociceptive activity of Ballota glandulosissima Hub.Mor. \& Patzak. Eastern Journal of Medicine, 9(2): 55-58.

44. Saltan Çitoğlu, G., Sever Yılmaz, B. \& Altanlar, N. 2003a. Antimicrobial activity of Ballota species growing in Turkey. Ankara Üniversitesi Eczacllık Fakültesi Dergisi, 32(2): 93-97.

45. Saltan Çitoğlu, G., Sever, B., Antus, S., Baitz-Gacs, E. \& Altanlar, N. 2003b. Antifungal flavonoids from Ballota glandulosissima. Pharmaceutical Biology, 41: 483-486.

46. Saltan Çitoğlu, G., Sever, B., Antus, S., Baitz-Gács, E. \& Altanlar, N. 2004c. Antifungal diterpenoids and flavonoids from Ballota inaequidens. Pharmaceutical Biology, 42(8): 659-663.

47. Sever Yılmaz, B., Altanlar, N. \& Saltan Çitoğlu, G. 2005. Antilisterial activity of Ballota species growing in Turkey. Ankara Üniversitesi Eczacılık Fakültesi Dergisi, 34(3): 155-164.
48. Sever Yılmaz, B., Özbek, H. \& Saltan Çitoğlu, G. 2006. Antinociceptive and anti-inflammatory activities of Ballota inaequidens. Pharmaceutical Biology, 44(8): 636-641.

49. Smith, D.W., Feankel, L.R., Mathers, L.H., Tang, A.T.S., Ariagno, R.L. \& Prober, C.G. 1991. A controlled trial of aerosolized ribavirin in infants receiving mechanical ventilation for severe respiratory syncytial virus infections. New England Journal of Medicine, 325: 24-29.

50. Tolon Fenercioğlu, E. \& Tuzlacı, E. 1998. Şile (İstanbul) halk hekimliğinde kullanılan bitkiler, 95-102, Paper presented at XII. Bitkisel Ilaç Hammaddeleri Toplantısı, 20-22 Mayıs, Hacettepe, Ankara-Türkiye.

51. Treanor, J. \& Falsey, A. 1999. Respiratory viral infections in the elderly. Antiviral Research, 44: 79-102.

52. Tuzlac1, E. \& Tolon, E. 2000. Folk medicinal plants of Şile (Istanbul, Turkey). Fitoterapia, 71: 673-685.

53. Valesi, A., Rodriguez, E., Velde, G.V. \& Mabry, T.J. 1972. Methylated flavonols in Larrea cuneifolia. Phytochemistry, 11: $2821-2826$.

54. Vanden Berghe, D.A.R., Haemers, A. \& Vlietinck, A.J. 1993. Antiviral agents from higher plants and an example of structural-activity relationships of 3-methoxyflavones. In: Colegate, S.M., Molyneux, R.J. (Eds.), Bioactive Natural Products, CRC Press, Boca Raton, 405-440 pp.

55. Wollenweber, E., Schober, I., Clark, W.D. \& Yatskievych, G. 1985. Flavonoid aglycones from leaf resins of two species Heterotheca (Compositae). Phytochemistry, 24(9): 2129-2131.

56. Wyde, P.R., Moore-Poveda, D.K., Hara, B., Ding, W.D., Mitsner, B. \& Gilbert, B.E. 1998. CL387626 exhibits marked and unusual antiviral activity against respiratory syncytial virus in tissue culture and in cotton rats. Antiviral Research, 38: 31-42.

57. Yeşilada, E., Honda, G., Sezik, E., Tabata, M., Fujita, T., Tanaka, T., Takeda, Y. \& Takaishi, Y. 1995. Traditional medicine in Turkey. V. folk medicine in the inner Taurus Mountains. Journal of Ethnopharmacology, 46: 133-152.

58. Yeşilada, E., Honda, G., Sezik, E., Tabata, M., Goto, K. \& Ikeshiro, Y. 1993. Traditional medicine in Turkey IV. Folk medicine in the Mediterranean subdivision. Journal of Ethnopharmacology, 39: 31-38. 